\title{
WHAT IS THE REAL IMPAIRMENT ON ESOPHAGEAL MOTILITY IN PATIENTS WITH GASTROESOPHAGEAL REFLUX DISEASE?
}

\author{
Angela FALCÃO' ${ }^{1}$, Ary NASI' ${ }^{1}$, Jeovana BRANDÃO², \\ Rubens SALLUM ${ }^{1}$ and Ivan CECCONELLO ${ }^{3}$
}

\begin{abstract}
Context - Impairment of esophageal motility is a common finding in patients with gastroesophageal reflux disease (GERD) as reduced lower esophageal sphincter (LES) basal pressure. A very low LES pressure might facilitate the occurrence of more gastroesophageal reflux whereas abnormal esophageal peristalsis may contribute to impaired esophageal clearance after reflux. Objective - Evaluate the esophageal motor function of the lower esophageal sphincter and esophageal body in the various forms of gastroesophageal reflux disease. Methods - The manometrics records of 268 patients, who had evaluation of the esophageal motility as part of the diagnostic gastroesophageal reflux disease were split into four groups, as follows: 33 patients who had no esophagitis; 92 patients who had erosive esophagitis; 101 patients who had short Barrett's esophagus and 42 patients who had long Barrett's esophagus. Results - The group who had long Barrett's esophagus showed smaller mean LES pressure and higher percentage of marked LES hypotonia; in the distal segment of the esophageal body the this group showed higher percentage of marked hypocontractility of the distal segment $(<30 \mathrm{~mm} \mathrm{Hg}$ ); this same group showed higher percentage of esophageal motility disorders. Conclusions - The most intense esophageal motility disorders and lower pressure of lower esophageal sphincter were noted in the group with long Barrett's esophagus. Those with reflux esophagitis and short Barrett's esophagus had esophageal motility impairment, intermediate among patients with esophagitis and long Barrett's esophagus. Patients with typical symptoms of gastroesophageal reflux but without esophagitis by endoscopy study showed no impairment of esophageal motility.
\end{abstract}

HEADINGS - Gastroesophageal reflux. Esophageal motility disorders. Barrett esophagus. Manometry.

\section{INTRODUCTION}

Gastroesophageal reflux disease (GERD) is common in children and adults but many aspects of its pathogenesis and natural course are not well established ${ }^{(11,29)}$. Impairment of esophageal motility is a common finding in patients with GERD and Barrett's esophagus $^{(2,4,5)}$ as reduced lower esophageal sphincter (LES) pressure, low peristaltic amplitude and/or impaired peristalsis in the esophageal body ${ }^{(5)}$. A very low LES pressure might facilitate the occurrence of more gastroesophageal reflux while abnormal esophageal peristalsis and lower distal esophageal peristaltic contractions may contribute to impaired esophageal clearance after reflux ${ }^{(3,16,36)}$.

It remains controversial whether the changes in esophageal peristalsis in patients with GERD is a primary abnormality or a consequence of pathological gastroesophageal reflux $(\mathrm{GER})^{(1,4,35)}$ and whether the intensity of this change contributes to increased esophageal mucosal injury ${ }^{(35)}$. Anyway, the relationship among GERD, esophageal peristalsis and esophageal mucosal changes has not been fully elucidated ${ }^{(25)}$, especially in our environment. So, the objective of this study was to evaluate the motility disorders and their relationship to the intensity of esophagitis and Barrett's esophagus length.

\section{METHODS}

We prospectively studied 268 consecutive patients with symptoms of GER who had been referred to esophageal manometry as part of the diagnostic investigation of GERD, aging 18 to 80 years old. In the no-esophagitis group only the patients with typical symptoms of GERD (heartburn and/or regurgitation) as the prevailing symptoms were selected. Exclusion criteria were previous gastric or esophageal

\footnotetext{
Declared conflict of interest of all authors: none

Esophageal Surgery Service, Digestive Surgery Division. Hospital das Clinicas da Faculdade de Medicina da Universidade de São Paulo (HC/FMUSP): ${ }^{2}$ Digestive Motility Service. Hospital Professor Edgard Santos - Universidade Federal da Bahia, Salvador, BA; ${ }^{3}$ Digestive Surgery Division, Department of Gastroenterology. Faculdade de Medicina da Universidade de São Paulo, São Paulo, SP, Brazil.

Correspondence: Dr. Angela Marinho Falcão - Rua Dr. Miranda de Azevedo, 1059, ap. 144 - Pompéia - 05027-000 - São Paulo, SP, Brasil. E-mail: angelacfalcao@terra.com.br
} 
surgery, patients with achalasia, esophageal or fundic varices, esophageal cancer, collagen diseases or previous ingestion of corrosive agents. All drugs that might interfere with esophageal motor function (i.e., nitrates, metoclopramide, and calcium-channel blocking agents) were discontinued at least 48 hours before the study.

Endoscopy was performed in all patients to assess the degree of esophageal mucosal injury. Barrett's esophagus was confirmed both endoscopically and histologically. The degree of mucosal injury was graded according to the Los Angeles classification ${ }^{(24)}$.

The 268 selected patients were divided into the following groups:

- No esophagitis group (NE): 33 patients showing only typical clinical complaints of GERD (heartburn and regurgitation), without esophagitis at endoscopy;

- Erosive esophagitis group (EE): 92 patients with erosive esophagitis (LA classification);

- Short Barrett's esophagus group (short BE): 101 patients with short $\mathrm{BE}(<3 \mathrm{~cm})$;

- Long Barrett's esophagus group (long BE): 42 patients with long $\mathrm{BE}(>3 \mathrm{~cm})$.

Standard water-perfusion esophageal manometry was performed with a Polygraph HR and a low-compliance perfusion system (Microcapillary Infusion System for Esophageal Manometry, both from Synetics Medical AB, Stokholm, Sweden) and with an 8-lumen catheter of $75 \mathrm{~cm}$ total length and $4.5 \mathrm{~mm}$ diameter with eight capillary channels $(0.8 \mathrm{~mm}$ of thickness) having each one hole for capturing the pressure. The procedure of esophageal manometry was performed according to a standard protocol, which is widely known in the specific literature ${ }^{(6)}$ and adopted in our laboratory by the station pull-through technique. All patients were studied in the supine position and performed 10 swallows of a $5 \mathrm{~mL}$ bolus of water at room temperature with an interval of at least 30 s between successive swallows ${ }^{(20)}$.

The following parameters were (i) LES - total length (in $\mathrm{cm}$ ), LES resting pressure (in $\mathrm{mm} \mathrm{Hg}$ ) measured at the mid respiratory level, percentage of severe LES hypotonia (when LES pressure was lower than or equal to $6 \mathrm{~mm} \mathrm{Hg}$ ); (ii) Esophageal body - esophageal peristaltic amplitude (in $\mathrm{mm}$ $\mathrm{Hg}$ ) at 3 and $18 \mathrm{~cm}$ above the upper LES margin, evaluation of the swallow complex propagation with identification of esophageal dismotility as: diffuse esophageal spasm (DES) was defined as simultaneous contractions in the esophageal body in $20 \%$ or more of wet swallows; ineffective esophageal motility (IEM) was defined as $30 \%$ of contractions in the distal esophagus are of low amplitude $(<30 \mathrm{~mm} \mathrm{Hg})$ and/or $30 \%$ of contractions are not transmitted ${ }^{(6,32)}$ and simultaneous contractions of the medial and distal segments in all the studied complexes $(100 \%)$.

The groups were compared according to the different manometric parameters, and to the demographic data (age and gender).

For statistical analysis we used the Pearson's chi-square test (estimated by the Monte Carlo method), the non-parametric Kruskal-Wallis' test with the Bonferroni's multiple comparisons tests. All numeric measurements are reported as mean plus or minus one standard deviation (mean $\pm 1 \mathrm{SD}$ ). A significance level (level of rejection of the nul hypothesis) of $0.05(5 \%)$ was considered for Pearson's chi-square and Kruskal-Wallis' tests; for the Bonferroni's multiple comparisons the $5 \%$ significance level was divided by the number of comparisons. Was used the SPSS version 13.0 software for Windows system.

\section{RESULTS}

\section{Demographics data}

The mean age $( \pm 1 \mathrm{SD})$ was 41.5 years $( \pm 12.0)$ in the no-erosive, 47.0 years $( \pm 14.1)$ in erosive esophagitis, 47.3 years $( \pm 15.3)$ in short Barrett's esophagus and 48.5 years $( \pm 16.0)$ in long Barrett's esophagus groups and they were similar $(P=0.157)$. There was a higher percentage of male patients in short Barrett's esophagus $(65.3 \%)$ and long Barrett's esophagus groups $(71.4 \%)(P=0.008)$ and predominantly female patients in the no-erosive $(69.7 \%)$ and erosive esophagitis group $(587 \%)(P<0.001)$ (Table 1).

TABLE 1 . The demographics date analyzed in the four study groups

\begin{tabular}{llcccc}
\hline & & NE & EE & SBE & LBE \\
\hline \multirow{6}{*}{ Gender } & Age & 41.36 & 46,98 & 47.32 & 48,43 \\
& & $( \pm 2.16)$ & $( \pm 1.48)$ & $( \pm 1.52)$ & $( \pm 2.49)$ \\
& Male & $30.40 \%$ & $41.40 \%$ & $61.20 \% *$ & $71.40 \% *$ \\
& Female & $69.50 \% *$ & $58.50 \% *$ & $38.70 \%$ & $28.50 \%$ \\
\hline
\end{tabular}

Distribution of the demographics date analyzed in the four study groups: NE (no esophagitis), EE (erosive esophagitis), SBE (short Barrett's esophagus) and LBE (long Barrett's esophagus). $(*)=P$ significant

\section{Manometric data}

The Table 2 shows details of mean ( \pm 1 SD) LES length, LES resting pressure and proximal $(18 \mathrm{~cm}$ above LES $)$ and distal (3 $\mathrm{cm}$ above LES) esophageal peristaltic amplitude. The table also displays the percent distribution of short LES (total LES length below $2 \mathrm{~cm}$ ), marked LES hypotonia (MRP $<6 \mathrm{~mm} \mathrm{Hg}$ ), marked hypotonia in the distal esophagus (amplitude below $30 \mathrm{~mm} \mathrm{Hg}$ ) and esophageal dismotility.

The patients with erosive esophagitis, short and long Barrett's esophagus had lower LES length $3.3( \pm 0.9), 3.4$ $( \pm 1.2), 3.1( \pm 1.3)$ respectively; $P=0.623$. However, the patients with long Barrett's esophagus had a higher percentage of the shorter LES length (11.9\%) when compared with erosive esophagitis and short Barrett's esophagus groups $(5.4 \%, 9.9 \%$ respectively $-P<0.001)$. The no-erosive group did not show any change.

The long Barrett's esophagus group had LES resting pressure (LESRP) lower [9.6 ( \pm 5.8$)]$ than the groups with erosive esophagitis [13.4 ( \pm 7.9$)]$ and short Barrett's esophagus [12.6 $( \pm 6.8)](P=0.006)$. The no-erosive group showed a mean value greater $[19.9( \pm 7.3)]$ than the other groups $(P<0.001)$.

With respect to the presence of LES marked hypotonia (LESRP $<6 \mathrm{~mm} \mathrm{Hg}$ ), the long Barrett's esophagus group had a higher percentage of marked LES hypotonia (30.9\%) 
TABLE 2. Distribution of the manometric variables analyzed in the four study groups

\begin{tabular}{|c|c|c|c|c|}
\hline \multirow[b]{2}{*}{ MANOMETRICS VARIABLES } & \multicolumn{4}{|c|}{ Study Groups } \\
\hline & NE & $\mathrm{EE}$ & SBE & LBE \\
\hline Mean LES total length $(\mathrm{cm})$ & $3.9 *( \pm 0.9)$ & $3.3( \pm 0.9)$ & $3.4( \pm 1.2)$ & $3.1( \pm 1.3)$ \\
\hline$\%$ of short LES (total length $<2 \mathrm{~cm}$ ) & $0 \%$ & $5.4 \%$ & $9.9 \%$ & $11.9 \% *$ \\
\hline LES resting pressure $(\mathrm{MRP}-\mathrm{mm} \mathrm{Hg})$ & $19.9 *( \pm 7.3)$ & $13.4( \pm 7.9)$ & $12.6( \pm 6.8)$ & $9.6( \pm 5.8)$ \\
\hline$\%$ LES Marked hypotonia (MRP $<6 \mathrm{~mm} \mathrm{Hg}$ ) & $0 \%$ & $10.9 \%$ & $8.9 \%$ & $30.9 \% *$ \\
\hline Mean proximal esophageal peristaltic amplitude $(\mathrm{mm} \mathrm{Hg})$ & $56.5( \pm 18.4)$ & $51.8( \pm 18.0)$ & $52.6( \pm 18.6)$ & $46.5( \pm 19.5)$ \\
\hline Mean distal esophageal peristaltic amplitude $(\mathrm{mm} \mathrm{Hg})$ & $116.1( \pm 41.0)^{*}$ & $92.4( \pm 48.0)$ & $74.2( \pm 31.9)$ & $69.6( \pm 35.3)$ \\
\hline$\%$ Marked hypocontractility in the distal esophagus $(<30 \mathrm{~mm} \mathrm{Hg})$ & $0 \%$ & $1.1 \%$ & $4.9 \%$ & $14.3 \% *$ \\
\hline \% Esophageal dismotility & $0 \%$ & $3.0 \%$ & $5.9 \%$ & $16.7 \% *$ \\
\hline
\end{tabular}

Manometric variables analyzed in the four study groups: NE (no esophagitis), EE (erosive esophagitis), SBE (short Barrett's esophagus) and LBE (long Barrett's esophagus). mm Hg: millimeters of mercury; cm: centimeters; LES: lower esophageal sphincter; MRP: mean resting pressure; $(*)=P$ significant.

compared to erosive esophagitis $(10.9 \%, P=0.006)$ and short Barrett's esophagus groups $(8.9 \%, P=0.001)$ which were similar $(P=0.809)$ (Figure 1).

There was no significant difference between groups in the proximal esophageal peristaltic amplitude $(18 \mathrm{~cm}$ above the LES $)(P=0.103)$. In the distal segment $(3 \mathrm{~cm}$ above the LES) the short and long Barrett's esophagus groups showed lower amplitude contractions [74.2 ( \pm 31.9); 69.6 $( \pm 35.3)$ respectively] $(P=0.001)$. The erosive esophagitis [ 92.4 $( \pm 48.0)]$ showed a lower amplitude compared to the no-erosive group $[116.1( \pm 41.0)](P<0.001)$.

The long Barrett's esophagus group had a higher percentage of marked hypocontractility of the distal esophageal contraction (amplitude below $30 \mathrm{~mm} \mathrm{Hg}$ ) [14.3\%] when compared to other groups $(\mathrm{EE}=1.1 \%$ and $\mathrm{SBE}=4.9 \%)$ $(P=0.003)$. The no-erosive group did not show any change (Figure 2).

Concerning esophageal peristalsis the long Barrett's esophagus group had a higher percentage of esophageal motility disorders $(16.7 \%)$ when compared to other groups $(\mathrm{EE}=3.0 \%$ and $\mathrm{SBE}=5.9 \%)(P=0.001)$. The NE group showed no change (Figure 3 ).

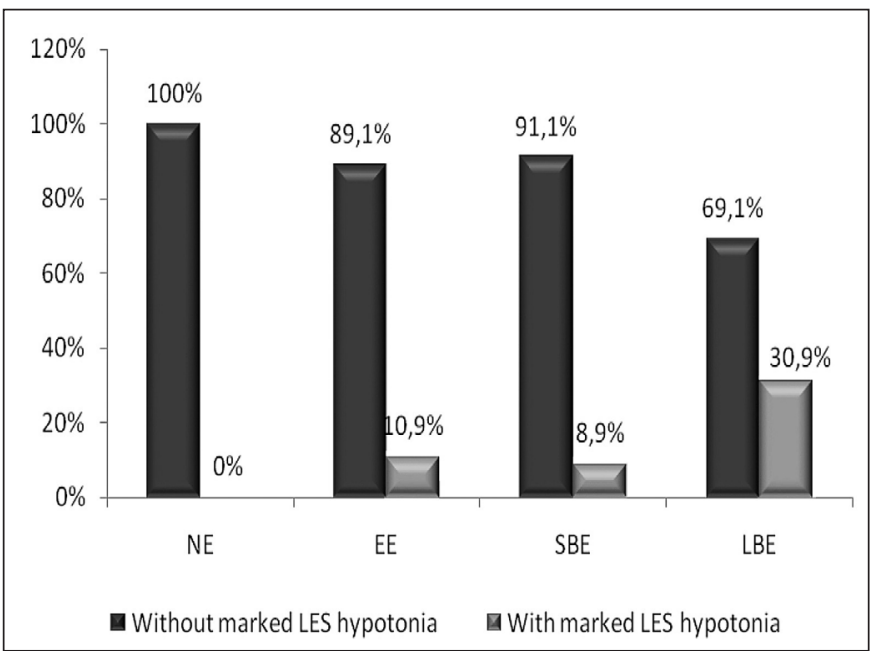

FIGURE 1. Percent distribution of patients with marked LES hypotonia $(\mathrm{MRP}<6 \mathrm{~mm} \mathrm{Hg}$ ) in the four study groups: $\mathbf{N E}$ (no esophagitis), EE (erosive esophagitis), SBE (short Barrett's esophagus) and LBE (long Barrett's esophagus). LES: lower esophageal sphincter; MRP: mean resting pressure

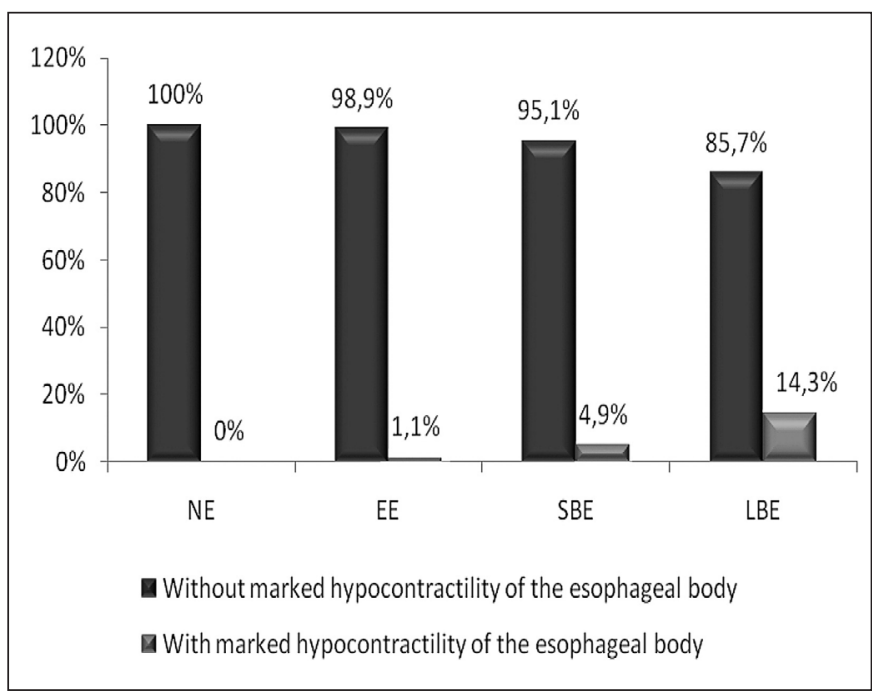

FIGURE 2. Percent distribution of patients with marked hypocontractility of the distal esophageal body (amplitude $<30 \mathrm{~mm} \mathrm{Hg}$ ) in the four study groups: NE (no esophagitis), EE (erosive esophagitis), SBE (short Barrett's esophagus) and LBE (long Barrett's esophagus)

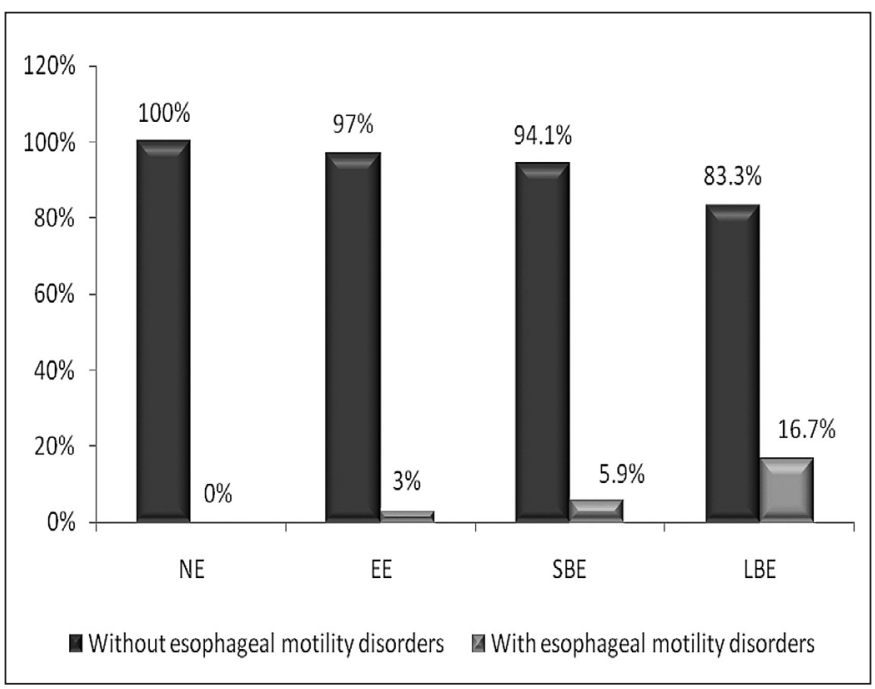

FIGURE 3. Percent distribution of esophageal motility disorders at the four study groups: NE (no esophagitis), EE (erosive esophagitis), SBE (short Barrett's esophagus) and LBE (long Barrett's esophagus) 


\section{DISCUSSION}

In this case series, age was similar in all groups, a fact also observed by other authors ${ }^{(7,25,37)}$. However, in some studies, older age was observed in patients with Barrett's esophagus $^{(3,36)}$. There was a higher percentage of male patients both in short and long Barrett's esophagus groups and female predominance in the no erosive and erosive esophagitis groups. Although Oliveira et al. ${ }^{(27)}$ found a slight predominance of males in the group with erosive esophagitis $(62.2 \%)$.

The LES is the first defense against the GER and is considered the most important factor in the physiopathology of GERD ${ }^{(3)}$. Changes in structure and function of the esophagogastric junction and LES may predispose to the development of GERD ${ }^{(23,31)}$.

In our study, patients with long Barrett's esophagus had both lower LES resting pressure and a higher percentage of marked hypotonia, also found by Clark et al. ${ }^{(10)}$ that identified LES marked hypotonia in greater frequency in patients with short and long Barrett's esophagus when compared to a control group. We also observed a higher percentage of shorter LES in patients with long Barrett's esophagus, as an indicator of a more severe antireflux barrier impairment. Therefore, there is a clear association of lower LES pressure and short LES length and esophageal mucosa injury, especially in relation to Barrett's esopha-

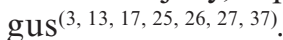

The esophageal body pressure and the normal peristaltic movement can be considered as factors that have an influence on the complete bolus transit ${ }^{(8)}$.

A videofluoroscopic study associated whith manometric showed that non-peristaltic contractions or distal esophageal body contractions less than $30 \mathrm{~mm} \mathrm{Hg}$ would not be effective to complete occlusion of the esophageal lumen and the complete emptying of the liquid bolus (contrast), suggesting that these changes would lead to an inefficient esophageal clearance ${ }^{(22,34)}$. Another study compared a combined multichannel intraluminal impedance with esophageal manometry (MII-EM) evaluates the functional aspects of esophageal contractions by simultaneously measuring bolus transit and esophageal contraction showed that the major factors to determine the complete bolus transit are the normal esophageal body pressure and normal peristalsis ${ }^{(8)}$.

In our study, the mean contraction amplitude in the proximal segment ( $18 \mathrm{~cm}$ above the LES) were normal in all groups. These data suggest that hypocontractility caused by GERD is located in the more distal esophagus when reflux exposure is more intense ${ }^{(14,15)}$.

However, the mean of the distal contraction amplitude was lower in short and long Barrett's esophagus groups. Moreover, there was no observed hypocontractility in the no-esophagitis group, which was also observed by Dantas et al. ${ }^{(15)}$. One must consider, however, that the swallows were performed with water (in bolus) and in the supine position.
It is known that there may be a variation in amplitudes of contraction and peristalsis in response to swallowing with water, but the 10 swallows performed during the manometry has been accepted as the minimum necessary for an adequate assessment $^{(20)}$

The percentage of esophageal body marked hypocontractility (amplitude below $30 \mathrm{~mm} \mathrm{Hg}$ ) was found almost only in patients with Barett's esophagus, particularly in the long Barrett's esophagus group. The difference was significantly higher when compared to erosive esophagitis group, as also observed by other authors ${ }^{(19,25,37)}$.

The impairment of esophageal motility is a common finding in patients with GERD. More than half of patients with GERD have change of the esophageal peristalsis, which are those with higher reflux and poor esophageal clearance ${ }^{(18)}$. It has been demonstrated that the decrease in the esophageal contraction amplitude may occur in patients without esophagitis but these changes are infrequent in these patients ${ }^{(33)}$.

Our data found that only groups with erosive esophagitis and both short and long Barrett's esophagus had some abnormal esophageal peristalsis. There was a relationship between the frequency of these amendments and intensity of mucosal injury, with a higher percentage of involvement in the long Barrett's esophagus group.

This fact coincides with the findings of Meneguetti et al. ${ }^{(25)}$ and Jorge et al. ${ }^{(21)}$ who also concluded that as the amount of mucosal damage increased from group without esophagitis to Barrett's esophagus, both esophageal motility and acid clearance worsened, suggesting that esophageal mucosal damage may contribute to esophageal dysmotility and worsening reflux ${ }^{(9)}$ and that there is a direct relationship between the impairment of motor function and severity of esophageal reflux esophagitis ${ }^{(4,30)}$.

In our study, functional changes were uncommon in the patients without esophagitis and more frequent and severe in patients with Barrett's esophagus, but it is difficult to explain why most patients with reflux esophagitis and even Barrett's esophagus showed no motor disorders.

These findings further suggest that the inflammatory process of GERD extending from the mucosa to the muscular layer resulting in hypocontractility ${ }^{(30,38)}$ and compromising the esophageal motility of several patients, but not in all. This would also explain why the results of surgical treatment of patients with long Barrett's esophagus are worse than in patients with erosive esophagitis ${ }^{(12,30)}$.

Finally, it should also be noted that patients were evaluated only once, so that the manometric alterations may be represented by a single time of clinical history of each one. Patients with GERD should be considered as a wide spectrum in which it is possible to move from one group to another in different degrees of esophagitis ${ }^{(28)}$. This does not mean that all patients will develop varying degrees of esophagitis, but we can say that without proper treatment, uncomplicated cases may progress to severe esophagitis or Barrett's esophagus irreversibly ${ }^{(30)}$. 
In conclusion, we observed that patients with typical symptoms of gastroesophageal reflux but without esophagitis by endoscopy study showed slight impairment of esophageal motor function. Those with EE and SBE showed an impairment of esophageal motor function intermediary between patients with esophagitis and LBE.
In patients with LBE we observed greater impairment of the LES as a lesser length, lower resting pressure and a higher percentage of severe hypotonia. This group also showed less contraction amplitude and a higher percentage of severe hypocontractility and changes in the distal esophageal peristalsis.

Falcão A, Nasi A, Brandão J, Sallum R, Cecconello I. Qual é o real comprometimento na motilidade esofágica em pacientes com doença do refluxo gastroesofágico? Arq Gastroenterol. 2013,50(2):111-6.

RESUMO - Contexto - Alteração no peristaltismo esofágico assim como diminuição do tônus basal do esfíncter inferior do esôfago são um achado comum em pacientes com doença do refluxo gastroesofágico. A presença de hipotonia acentuada do esfíncter inferior do esôfago pode facilitar a ocorrência de refluxo gastroesofágico mais intenso e a presença de alteração no peristaltismo esofágico pode contribuir para uma deficiente depuração esofágica. Objetivo - Avaliar a função motora do esfíncter inferior do esôfago e do corpo esofágico nas várias formas da doença do refluxo gastroesofágico. Métodos - Avaliaram-se os prontuários de 268 pacientes, que realizaram manometria esofágica como parte da investigação diagnóstica da doença do refluxo gastroesofágico. Os pacientes foram distribuidos em quatro grupos: 33 pacientes que não tinham esofagite, 92 pacientes que tinham esofagite erosiva; 101 pacientes que tinham esôfago de Barrett curto e 42 pacientes que tinham esôfago de Barrett longo (grupo EBL). Resultados - O grupo dos que tinham EBL, apresentou menor média de pressão do esfíncter inferior do esôfago e maior percentual de hipotonia acentuada do esfíncter inferior do esôfago; no segmento distal do corpo do esôfago, este grupo apresentou maior percentual de hipocontratilidade acentuada $(<30 \mathrm{~mm}$ $\mathrm{Hg}$ ). O grupo dos que tinham EBL apresentou maior porcentagem de distúrbios da motilidade esofágica. Conclusões - As alterações mais intensas na motilidade esofágica e no esfíncter inferior do esôfago foram observadas no grupo com EBL. Aqueles com esofagite de refluxo e esôfago de Barrett curto tiveram comprometimento da função motora esofágica, intermediárias entre os pacientes sem esofagite e com EBL. Os doentes com sintomas típicos de refluxo gastroesofágico, mas sem esofagite ao estudo endoscópico, não apresentaram comprometimento da função motora esofágica.

DESCRITORES - Refluxo gastroesofágico. Transtornos da motilidade esofágica. Esôfago de Barrett. Manometria. 


\section{REFERÊNCIAS}

1. Aben-Athar CG, Dantas RO. Primary and secondary esophageal contractions in patients with gastroesophageal reflux disease. Braz J Med Biol Res. 2006;39:102731.

2. Achem AC, Achem SR, Stark ME, DeVault KR. Failure of esophageal peristalsis in older patients: association with esophageal acid exposure. Am J Gastroenterol. 2003;98:35-392.

3. Alonso O, Hernández D, Moreno E, Manrique A, Moreno A, García-Sesma A, Calvo J. The real value of lower esophageal sphincter measurement for predicting acid gastroesophageal reflux or Barrett's esophagus. J Gastrointest Surg. 2005;9:973-79.

4. Ang D, Blondeau K, Sifrim D, Tack J. The spectrum of motor function abnormalities in gastroesophageal reflux disease and Barrett's esophagus. Digestion. 2009;79:158-68

5. Boeckxstaens GE. Review article: the pathophysiology of gastro-oesophageal reflux disease. Aliment Pharmacol Ther. 2007;26:149-60.

6. Bremner C, DeMeester TR, Bremner RM, Mason RJ. Esophageal motility testing: Made easy, 2001; chapter 2:13-51

7. Campos GM, DeMeester SR, Peters JH, Oberg S, Crookes PF, Hagen JA, Bremner CG, Sillin LF 3rd, Mason RJ, DeMeester TR. Predictive factors of Barrett's esophagus: multivariate analysis of 502 patients with GERD. Arch Surg. 2001;136:1267-73.

8. Cho YK, Choi MG, Park JM, Oh JH, Paik CN, Lee JW, Lee IS, Kim SW, Chung IS. Evaluation of esophageal function in patients with esophageal motor abnormalities using multichannel intraluminal impedance esophageal manometry. World J Gastroenterol. 2006;12: 6349-54.

9. Chrysos E, Prokopakis G, Athanasakis E, Pechlivanides G, Tsiaoussis J, Mantides A, Xynos E. Factors affecting esophageal motility in gastroesophageal reflux disease. Arch Surg. 2003;138:241-46.

10. Clark GW, Ireland AP, Peters JH, Chandrasoma P, DeMeester TR, Bremner CG. Short-Segment Barrett's Esophagus: a prevalent complication of gastroesophageal reflux disease with malignant potential. Gastrointest Surg. 1997;1:113-22.

11. Coron E, Hatlebakk JG, Galmiche JP. Novel developments in non-erosive and erosive gastroesophageal reflux disease. Curr Opin Gastroenterol. 2006,22:399-405.

12. Csendes A, Braghetto I, Burdiles P, Puente G, Korn O, Díaz JC, Maluenda F. Long term results of classic antireflux surgery in 152 patients wiyh Barrett's esophagus: clinical, radiological, endoscopic, manometric and acid reflux test analysis before and late after operation. Surgery. 1998;123:645-57.

13. Csends A, Smok G, Quiroz J, Burdiles P, Rojas J, Castro C, Henríquez A. Clinical, Endoscopic and Funtional studies in 408 patients wiyh Barrett's Esophagus compared to 174 cases of intestinal metaplasia of the cárdia. Am J Gastroenterology. 2002;97:554-60.

14. Dantas RO, Aprile LR. Esophageal striated muscle contractions in patients with gastroesophageal reflux symptoms. Dig Dis Sci. 2002;47:2586-90.

15. Dantas RO, Aprile LR. [Aging and esophageal motility in patients with gastroesophageal refl ux disease]. Arq Gastroenterol. 2006;43:107-11.

16. Fornari F, Blondeau K, Durand L, Rey E, Diaz-Rubio M, De Meyer A, Tack J, Sifrim D. Relevance of mild ineffective oesophageal motility (IOM) and potential pharmacological reversibility of severe IOM in patients with gastro-oesophageal reflux disease. Aliment Pharmacol Ther. 2007;26:1345-54.

17. Frazzoni M, Manno M, De Micheli E, Savarino V. Pathophysiological characteristics of the various forms of gastro-oesophageal reflux disease. Spectrum disease or distinct phenotypic presentations? Dig Liver Dis. 2006;38:643-648.

18. Ho SC, Chang CS, Wu CY, Chen GH. Ineffective esophageal motility is a primary motility disorder in gastroesophageal reflux disease. Dig Dis Sci. 2002;47:652-6.

19. Iwakiri K, Sugiura T, Hayashi Y, Kotoyori M, Kawakami A, Makino H, Nomura T, Miyashita M, Takubo K, Sakamoto C. Esophageal motility in Japanese pacients with Barrett's esophagus. J Gastroenterology. 2003;38:1036-41.
20. Jalil S, Sperandio M, Tutuian R, Castell DO. Are 10 wet swallows an appropriate sample of esophageal motility? Yes and no. J Clin Gastroenterol. 2004;38:30-4.

21. Jorge JX, Almeida CC, Borges CI, Delgado FJ, Simões MA, Silva AL, Coelho AC. Effects of gastroesophageal reflux on esophageal motility. Rom J Intern Med. 2012:50:233-9.

22. Kahrilas PJ, Dodds WJ, Hogan WJ. Effect of peristaltic dysfunction on esophageal volume clearance. Gastroenterology. 1988;94:73-80.

23. Kahrilas PJ. GERD pathogenesis, pathophysiology, and clinical manifestations. Clev Clin J Med. 2003;70:S4-S19.

24. Lundell LR, Dent J, Bennett JR, Blum AL, Armstrong D, Galmiche JP, Johnson F, Hongo M, Richter JE, Spechler SJ, Tytgat GNJ, Wallin L. Endoscopic assessment of oesophagitis: clinical and functional correlates and further validation of the Los Angeles classification. Gut. 1999;45:172-80.

25. Meneghetti AT, Tedesco P, Damani T, Patti MG. Esophageal mucosal damage may promote dysmotility and worsen esophageal acid exposure. J Gastrointest Surg. 2005;9:1313-7.

26. Oh DS, Hagen JA, Fein M, Bremner CG, Dunst CM, DeMeester SR, Lipham J, DeMeester TR. The impact of reflux composition on mucosal injury and esophageal function. J Gastrointest Surg. 2006;10:787-97.

27. Oliveira C, Nasi A, Falcão A, Cecconello I, Gama-Rodrigues JJ. As alterações da mucosa esofágica devem ser valorizadas na caracterização endoscópica da esofagite por refluxo? Arq Bras Cir Dig. 2003;16:130-33.

28. Pace F, Pallotta S, Vakil N. Gastroesophageal reflux disease is a progressive disease. Dig Liver Dis. 2007;39:409-14.

29. Pandolfino JE, Kwiatek MA, Kahrilas PJ. The pathophysiologic basis for epidemiologic trends in gastroesophageal reflux disease. Gastroenterol Clin North Am. 2008,37:827-43.

30. Pollara WM. Esôfago de Barrett: diagnóstico, tratamento e seguimento tardio (Tese de Doutorado - Faculdade de Medicina da Universidade de São Paulo) São Paulo, 1987.

31. Sidhu A, Triadafilopoulos G. Neuro-regulation of lower esophageal sphincter function as treatment for gastroesophageal reflux disease. World J Gastroenterol. 2008;4:985-90

32. Spechler SJ, Castell DO. Classification of oesophageal motility abnormalities. Gut. 2001;49:145-51

33. Stein HJ, DeMeester TR. Outpatient physiologic testing and surgical management of foregut motility disorders. Curr Probl Surg. 1992;29:413-555.

34. Stein HJ, Singh S, DeMeester TR. 'Efficacy' of esophageal peristalsis: a manometric parameter to quantify esophageal body dysfunction. Dis Esophagus. 2004; 17,297-303.

35. Tack J. Recent developments in the pathophysiology and therapy of gastroesophageal reflux disease and nonerosive reflux disease. Curr Opin Gastroenterology. 2005,21:454-60.

36. Tutuian R, Castell DO. Clarification of the esophageal function defect in patients with manometric ineffective esophageal motility: studies using combined impedance-manometry. Clin Gastroenterol Hepatol. 2004;2:230-6.

37. Zaninotto G, Portale G, Parenti A, Lanzal C, Costantini M, Molena D, Ruol A, Battaglia G, Costantino M, Epifani M, Nicoletti L. Role of acid and bile reflux in development of specialised intestinal metaplasia in distal oesophagus. Dig Liver Dis. 2002;34:251-7.

38. Zentilin P, Conio M, Mele MR, Mansi C, Pandolfo N, Dulbecco P, Gambaro C, Tessieri L, Iiritano E, Bilardi C, Biagini R, Vigneri S, Savarino S. Comparison of the main oesophageal pathophysiological characteristics between short- and long-segment Barrett's oesophagus. Aliment Pharmacol Ther. 2002;16:893-8.

Received 3/12/2012. Accepted 15/4/2013. 